胃癌のリンパ管侵襲に関する病理組織学的検討

$\begin{array}{llllr}\text { 川角 博規 } & \text { 鳥取大学第 } 1 \text { 外科 } & & \\ \text { 万木野 } & \text { 正人 } & \text { 竹林 } & \text { 正孝 } \\ \text { 西土井英昭 } & \text { 岡本 } & \text { 恒之 } & \text { 木村 } & \text { 修 } \\ \text { 信明 } & \text { 古賀 } & \text { 成昌 }\end{array}$

\title{
HISTOLOGICAL STUDIES ON LYMPHATIC INVASION IN GASTRIC CANCER
}

\author{
Hiroki KAWASUMI, Masato MAKINO, Masataka TAKEBAYASHI, \\ Eiichi YURUGI, Tsuneyuki OKAMOTO, Osamu KIMURA, \\ Hideaki NISHIDOI, Nobuaki KAIBARA and Shigemasa KOGA \\ 1st Department of Surgery, Tottori University School of Medicine
}

深達度 $\mathrm{m}$ の癌と多発癌を除き治瘜切除された胃癌 308 例 ( $\mathrm{sm}$ 早期胃癌86例, 進行胃癌222例)につい て,リンパ管侵襲 ly とその他の因子との関係について検討した. ly の程度とリンバ節転移率及びリン パ節転移度とは密接な関係にあった．組織型との関係をみると，1y 高度例は䯣様型低分化腺癌に多く みられ，硬性型低分化腺癌ではly はあっても，これを光顕的に見出しえない例も少なからずあるので はないかと推察された．胃癌の壁梁達度は同じでも，1yの存在部位が深いものでは, リンパ節転移は 高度となり, 予後も不良となる傾向にあり, ly の胃壁内存在部位を検討することは胃癌のリンパ行性 転移の量的指標の 1 つとなり，ひいては患者予後を示唆する因子の1つとなるものと考学る.

索引用語：胃癌のリンバ管侵襲, 胃癌のリンパ節転移率, 胃癌のリンパ節転移度, 胃癌の組織型, 胃癌生存率

はじめに

リンパ管侵襲（以下ly）のみられる胃癌の予後はそ らでないすのに比べて不良であり，量的には， ly が多 ければ多いはど患者の予後が不良になることは, つと に知られている事実である ${ }^{122}$. しかし, ly の存在部位 と予後との関係を論じた研究はあまりみられない。

胃癌に批ける $\mathrm{y}$ の存在部位としては, 粘膜下層と浆 膜下層が主なものであるが，胃癌の壁深達度が深くな ればなるはど，患者の予後が不良となるように，y y その存在部位が胃壁深層になるにつれて，予後に与兄 る影響が出てくるのではないかと思われる.

このよらな観点から，われわれは胃癌のリンパ管侵 襲所見について再検討を加光たところ，若干の興味あ る知見が得られたので報告する。

$<1985$ 年 3 月 13 日受理 > 別刷請求先：川角 博規 T683 米子市西町 $36-1$ 鳥取大学医学部第 1 外科
対象と方法

1978年から1983年までの 6 年間に鳥取大学第 1 外科 で切除された原発胃癌は450例であるが, このらち粘膜 内癌, 多発癌及び非治瘾切除例を除いた治瘾切除例 308 例 (sm 早期胃癌86例, 進行胃癌222例) を本研究の対 象とした。切除胃は $10 \%$ ホルマリン固定後, 早期胃癌 では $5 \mathrm{~mm}$ 間隔の全割切片, 進行胃癌では癌巣中央部及 びそれより少し離れた両側の 3 切片にて組織標本を作 製した. ly の判定に際しては, リンパ管腔中に癌細胞 群のみられる所見をlyとし，同時に行ったWeigert 染色により静脈唚襲とは区別した，検索した組織標本 3 切片について, ly が全くない場合を $\mathrm{ly}_{0}, 1 \sim 3$ 個の 場合を $\mathrm{ly}_{1}, 4 \sim 6$ 個を $\mathrm{ly}_{2}, 7$ 個以上の場合を $\mathrm{ly}_{3}$ とし て表わした.

リンパ節については, Hilus を含む長軸方向の中心 1 カ所から組織標本を作製して転移の有無を検索し た。なお，本文中に示したリンパ節転移度とは，検索 したリンパ節総数に対する転移陽性リンパ節数の割合 
であり，転移が第 1 群リンパ節にとどまっている場合 には母数を第 1 群リンパ節総数とし, 転移が第 2 群あ るいは第 3 群リンパ節に及ぶ場合には，母数をそれぞ れに対応するリンパ節総数として表わした，その他の 所見の記載はすべて胃癌取扱い規約 ${ }^{3} に$ 従い，有意差 検定には $x^{2}$ 検定を用いた。

\section{成 績}

1. 胃癌の肉眼型及び占居部位とリンパ管侵襲

進行胃癌222例の肉眼型と $\mathrm{ly}$ の関係をみると（図 1), ly 陽性率は Borrmann 1 型44\%(4/9)， 2 型90\% $(45 / 50), 3$ 型 $82 \%(77 / 94), \quad 4$ 型75\% (33/44)， 5 型 66\% (19/29) であり, Borrmann 2 型, 3 型に㧊いて 高率であった。 また $\mathrm{y}_{3}$ 陽性率は Borrmann 2 型 (40\%)，3 型(43\%)，4 型(57\%)であり，Borrmann 1 型では $\mathrm{ly}_{3}$ 陽性例は全く認められなかった。

次に, 癌浸潤が 3 領域に及ぶ症例を除いた286例の病 巣占居部位々 ly の関係をみると(図 2), 上部胃癌 (C) に和けるly 陽性率は80\%（32/40）であり，中部胃癌 (M) の52\% (64/123), 下部胃癌 (A) の57\% (70/123) に比較し有意に高率で $(\mathrm{p}<0.05)$, しかも ly の程度も 高度な例が多かった。

2.リンパ管侵襲とリンパ節転移率及びリンパ節転 移度

今回対象とした胃癌症例のうち, sm癌に拈ける $\mathrm{ly}$ 陽性率とリンパ節転移率はそれぞれ19.3\%，12.5\%，

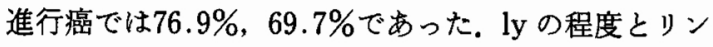
八゚節転移率の関係をみると, $\mathrm{y}($ (一)の症例では転移陽 性率は14.8\%（18/222）であったが，y（+）例では

囝 1 肉眼型とリンパ管侵襲

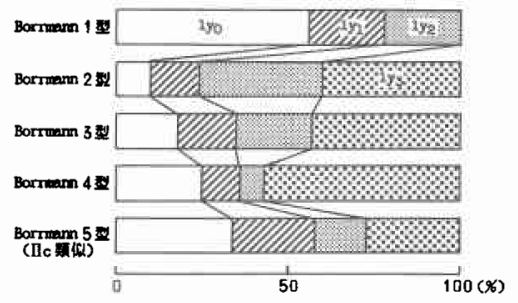

図2 占居部位とリンパ管侵襲

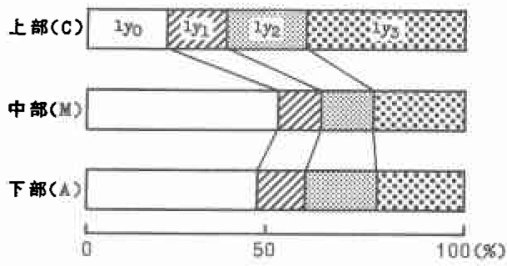

78.6\%(147/187) と高率であった. そして ly の程度が 高度になるにつれてりンパ節転移率も上昇したが，一 方ではly (-) で $\mathrm{n}(+)$ 症例 $\left(\mathrm{n}_{1}(+)\right.$ 15例, $\mathrm{n}_{2}(+)$ 3 例), あるいは逆に $\mathrm{ly}_{2}$ や $\mathrm{ly}_{3}$ でn (一) 症例 $\left(\mathrm{ly}_{2} 11\right.$ 例， $\mathrm{ly}_{3} 7$ 例）す少なからず認められた（図 3).

次に, ly の程度とリンパ節転移度の関俰をみると (図 4 ), 転移度が40\%以下の場合には, $\mathrm{ly}_{0}$ から $\mathrm{ly}_{3}$ まで の種々の症例がみられたが, 全体としては転移度が高 度になるにつれて ly の程度も高くなる傾向にあり, 転 移度が $80 \%$ 以上の場合にはすべて $1 \mathrm{y}_{3}$ 症例であった。

3. 組織型とリンパ管侵襲

胃癌の組織型のうち乳頭腺癌 (pap), 高分化型管状 腺癌 $\left(\mathrm{tub}_{1}\right)$ ，中分化型管状腺癌 $\left(\mathrm{tub}_{2}\right)$ を高分化型之 し, 低分化腺癌 (por) 及び印環細胞癌 (sig) を低分化 型として，両者が混在する場合には，優勢像をるって それぞれの優位型として 4 型に大別し，y の程度との 関係を検討した（図 5 ）．1y陽性率は高分化型で53\% (37/70), 高分化優位型で66\%(37/56), 低分化優位型 で70\%（49/70），低分化型で55\%（63/115） と各組織 型間で有意差は認められなかったが, $\mathrm{ly}_{3}$ 陽性率は低分 化型あるいは低分化優位型で高い傾向が認められた。 そこで印環細胞癌を除く低分化腺癌162例の間質量と ly の関係をみると（図 6), ly 陽性率は硬性型で67\% (59/88), 中間型で55\% (26/47), 髄様型で81\%（22/ 27) と䔕様型に怙いて高率であり, 特に $\mathrm{ly}_{3}$ 陽性率は㵦

四 3 リンパ管侵襲とリンパ節転移率

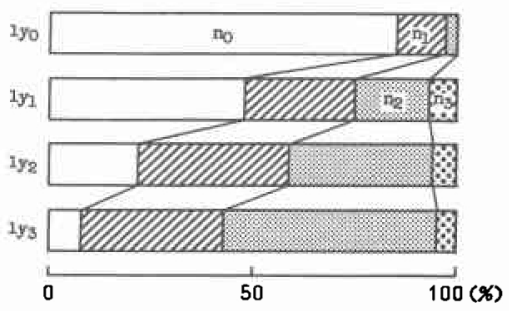

园 4 リンパ管侵襲とリンパ節転移度

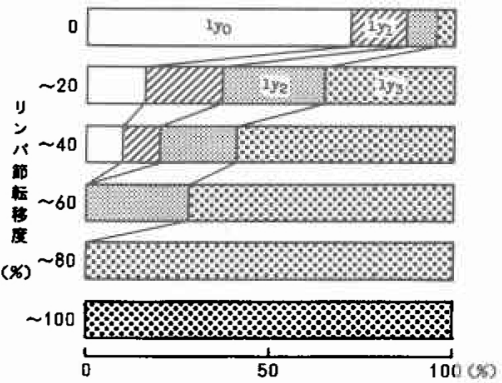


困 5 組織型とリンパ管侵襲

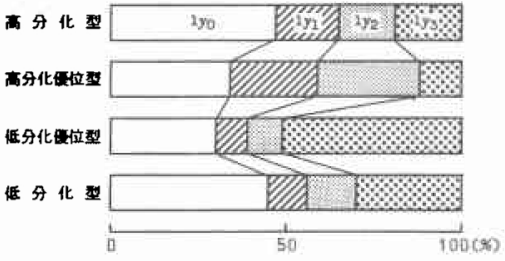

図 6 低分化腺癌の間質量とリンパ管侵襲

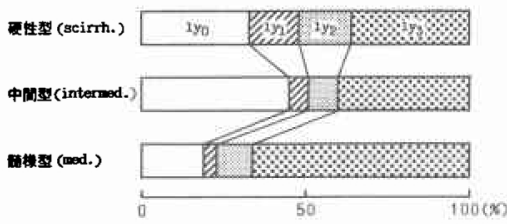

様型で高率であった。

次に, lyとリンパ節転移率の相関しない症例が 308 例中36例 $(11.6 \%)$ に認められたので，このよ5な例 では癌の組織型に特徴があるかどらかを検討した（表 1,2). $1 \mathrm{y}(+)$ でn (一) 症例は18例 ( $\mathrm{ly}_{2} 11$ 例, $\mathrm{ly}_{3}$ 7 例）みられたが，癌の組織型との間には一定の傾向 は認められなかった。逆にly (一) で $\mathrm{n}(+)$ 症例も 18 例 ( $\mathrm{n}_{1}(+)$ 15例, $\mathrm{n}_{2}$ (十) 3 例) みられたが, その組 穖型をみると，低分化型あるいは低分化優位型が78\% （14/18）を占めており，しか子硬性型が $64 \%$ と高率で あった。

4. リンパ管侵襲の胃壁内存在部位とリンパ節転移 ly が霄壁のいかなる部位にみられるかということ と、リンパ節転移率とは密接な関係があるのではない

表 1 ly (+) でn (-) 症例 $\left(\mathrm{ly}_{2} 11\right.$ 例, $\mathrm{ly}_{3} 7$ 例 $)$

\begin{tabular}{|c|c|c|c|c|}
\hline & 高分化 & 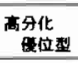 & $\begin{array}{c}\text { 低分化 } \\
\text { 位烈 }\end{array}$ & 组分化型 \\
\hline $1 y(+) n(\rightarrow)$ & 5 & 4 & 3 & 6 \\
\hline$(n=18)$ & (28) & (22) & (17) & (33) \\
\hline
\end{tabular}

表 2 ly (-) で $\mathrm{n}(+)$ 症例 $\left(\mathrm{n}_{1}(+)\right.$ 15例, $\mathrm{n}_{2}(+)$ 3 例)

\begin{tabular}{|c|c|c|c|}
\hline 高分化嫼 & 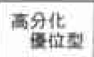 & 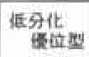 & 海牙化型 \\
\hline 2 & 2 & 1 & 13 \\
\hline \multicolumn{2}{|c|}{$22 x$} & \multicolumn{2}{|c|}{$78 \%$} \\
\hline
\end{tabular}

表 3 壁深達度が ss 又は se 症例に括けるリンパ管侵 襲の存在部位とリンパ節転移

\begin{tabular}{|c|c|c|c|c|c|}
\hline \multirow{2}{*}{ 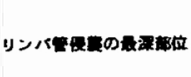 } & \multicolumn{4}{|c|}{ 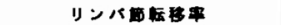 } & \multirow{2}{*}{ 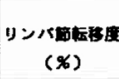 } \\
\hline & $\mathrm{n}_{0}$ & $n_{1}$ & $\mathrm{n}_{2}$ & $n_{3}$ & \\
\hline $\mathrm{s} m$ & 7 & 15 & 17 & 0 & $20.92 \pm 17.73$ \\
\hline$(n=39)$ & $(17.9)$ & (30.5) & (45.6) & (0) & \\
\hline s s & 0 & 9 & 19 & 6 & $30.12 \pm 21.65$ \\
\hline$(n=34)$ & $(0)$ & $(26.5)$ & (55.9) & $(27.6)$ & \\
\hline
\end{tabular}

図7壁深達度がss 又はseの stage III 症例におけ る ly の存在部位からみた累積生存率

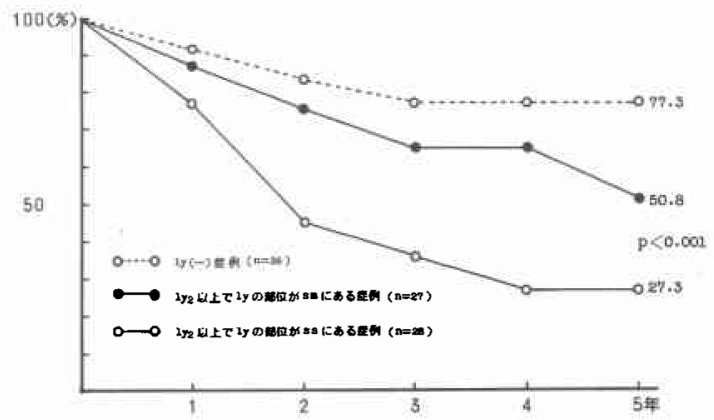

かと思われる。そこで胃癌の深達度がss 又はseでし かも $\mathrm{ly}_{2}$ 以上の症例を対象として，ly の胃壁最深部位 とリンパ節転移率の関係を調べた. ly の胃壁最深部位 が pm にある例は 7 例と少ないため，これを除いた ly の最深部位が sm とs にある例についてみると（表 3 ), ly の最深部位が sm にある例ではリンパ節転移陽 性率は $82 \%$ （32/39）であったが，ssにly がみられる 例ではすべてにおいてリンパ節転移がみられた。また ly が sm にある症例では，リンパ節転移率の程度も軽 かったが, ly がss に達する症例ではりンパ節転移率の 程度が高度になり， $\mathrm{n}_{3}(+)$ も $17.6 \%(6 / 34)$ に認めら れた。同様の傾向はリンパ節転移度においてもみられ た.

一方これらの症例について ly の最深部位別に予後 をみると, ly の最深部位が sm にみられる例では, 5 年 生存率が $60.4 \%$ あるのに対して, ly がssにみられる 例ではわずかに $29.8 \%$ であり, ly の胃壁内存在部位と 患者予後との間には密接な関係のあることが示され た.このような検討を stage 3 症例に限っておこなっ てみても全く同様の傾向がみられ, ly の最深部位が 
sm にある例（n=28）では 5 生率50.8\%であったが, ss にある例（n=27）では27.3\%であった（図7).

\section{考 察}

胃癌の予後を左右する大きな因子として、リンパ節 転移及び浆膜浸潤の有無などがあげられるが，これら の中でもリンパ節転移は, 郭清の優劣が患者の予後に 直接関係する因子として重要視されている.このため, リンパ節転移と密接な関係にある ly については, 特に 早期胃癌を対象として多くの研究がなされている。こ れは早期胃癌では組織像の多様性が少なく, 癌の進展 形式が進行胃癌ほど複雑ではなく，また y は多くは粘 膜下層に限ってみられるために，一連のリンパ系進展 の初期像としてとらえやすいためと思われる。しかし， ly は粘膜下層だけでなく，浆膜下層にる多く認められ るので, われわれは癌深達度が $\mathrm{sm}$ 以下の症例を対象 として, 胃癌のリンパ管侵襲に関する病理組織学的検 討を試みた。

ly がリンパ節転移のはじまりであり，互いに相関す るであろうことは想像に難くない，今回の検討でも， ly (一) 症例におけるリンパ節転移陽性率は $14.8 \%$ で あったが, ly (十) では78.6\%と高率になり, ly の程 度が高度になるにつれてリンパ節転移率も高率となっ た。一方，リンパ節転移度と ly の程度む密接な関係に あり，転移度が $80 \%$ 以上の症例ではすべてが $\mathrm{y}_{3}$ であ

り，これらの予後は極めて不良であった。

胃癌の組織型とリンパ節転移の関保については，従 来より多くの検討がなされているが，諸家によりその 見解に若干の差がみられる。脇䛀仙単純癌の転移率 が高く, 間質量との関係では, 硬性癌が転移しやすく 膠様腺癌や印環細胞癌はリンパ節転移を扣こしにくい と報告し，鈴木ら5) は早期胃癌を対象として，低分化腺 癌が他の組織型にくらべてリンパ節転移が高率であ $\eta$, 乳頭腺癌, 中分化型管状腺癌, 印環細胞癌に括い ては有意差はなかったと報告している。また吉野6は 進行癌を含めて検討し, 腺管腺癌のリンパ節転移率が 最も高く乳頭腺癌が最も低く，間質量からみると硬性 型が転移しやすいと述べている.川口王は，原発巣に打 いて癌組織量の多い組織型がリンパ節転移をおこしや すく，とくに粘膜層及び粘膜下層に存在する組織型が 高率に転移し, 組織型別では, 分化型と低分化型腺癌 が混在する場合には分化型腺癌の転移率が高く，硬性 型低分化腺癌及び印環細胞癌では転移をおこしにくい と報告している．宮本ら ${ }^{8)}$ 高分化型にリンパ節転移 は多く，低分化型単独ではリンパ節転移は少ないが,
低分化型優勢の混合型では高率であったとして，両者 の癌細胞核 DNA 量パターンの相違を指摘してい る9).このように報告者により結果が異なるのは, 癌の 組織分類や対象とした症例の壁深達度がそれぞれ違ら ことによると思われ，単純な比較は困難である．われ われの検討では, ly の高度な症例が低分化腺憈に打い て高率に認められ，また間質量とlyの関係を調べる と, ly 陽性率は硬性型の $67 \%$ に対し蹎様型では $81 \%$ と 高率で, とくに $\mathrm{y}_{3}$ 陽性率が高いことから，髄様型低分 化腺癌はlyをきたしやすい傾向にあるのではないか と考克られる。

しかし，ly(一)と診断されたにもかかわらずリンパ 節転移のみられた症例について，その組織型を検討す ると，多くは低分化腺癌でしかも硬性型であったこと により, 硬性型低分化腺癌では実際にlyはあっても光 䫒的に見出しえない例も少なからずあるすのと思われ る.すなわち、リンパ管内に侵入した癌細胞が栓塞様 に一塊としてリンパ管内に存在する状態では, ly とし て光顕レペルでとらえられるが，硬性型の低分化腺癌 においては癌細胞が小さくまばらであり，間質も線維 化が強くリンパ管内皮細胞も識別しにくいため, ly と して見出し難いるのと推察される.

次に, ly の胃壁最深部位とリンパ節転移及び患者予 後との関係を, 壁樑達度 ss 又は se の症例について検 討したところ，かなり興味ある結果が示された。すな わち, ly の最深部位が ss にみられる例と smにみられ る例を比較すると，リンパ節転移率及びリンパ節転移 度のいずれをみても前者が有意に高く，また予後をみ ても，yが ss にみられる例は，それが smにみられた ものに比べて極めて不良であった，以上の事実より， lyの胃壁最深部位を検討することは胃癌のリンパ行 性転移の量的指標の 1 つとり,ひいては患者の予後 を示唆する因子の 1 つになるるのと思われる.

\section{まとめ}

1978年から1983年までの 6 年間に鳥取大学第 1 外科 において手術された sm 胃癌86例及びそれ以上の壁深 度を示した治㾤手術胃癌222例を対象として癌巣内 $1 \mathrm{y}$ とリンパ節転移, 予後との関係を検討し, 以下の結果 をえた。

1. ly の程度とリンパ節転移率及びリンパ節転移度 とは密接な関係にあった。

2. $1 \mathrm{y}$ 高度例は䯣様型低分化腺癌に多くみられた。

3. 硬性型低分化腺癌では ly はあってもそれを光顕 的に見出しえない例む少なからずあるのではないかと 
推察された。

4. 癌の胃壁深達度は同じであっても, ly の存在部 位が深いるのでは, リンパ節転移は高度となり, 予後 る不良になる傾向がみられた。

本論文の要旨は第24回日本消化器外科学会総会に招いて 発表した。

\section{文献}

1）佐野量造, 厷田映五, 下田忠和注加：早期胃癌再発 死亡例の病理学的検討. 胃之腸 $5: 531-540$, 1970

2）東弘, 小川道雄, 藤本二郎注か：胃癌の治療成 辕とそれを左右する因子，日癌治療会誌 16 ： 110-111, 1981

3）胃癌研究会編：外科·病理・胃癌取扱い規約, 東京, 金原出版，1979
4）脇坂順一：胃癌の病理組織学的検討。外科治療 $22: 121-129, \quad 1970$

5）鉿木博孝, 遠藤光夫，山下由紀子ほか：早期胃癌に 抢けるリンパ節転移の検討. 日消外会誌 17 ： 1517--1526, 1984

6）吉野鍳一：胃癌のリンパ節転移に関する外科病理 学的知見補遺. 日外会誌 $72: 1634-1646,1971$

7）川口廣樹：胃癌原発巣とりンパ節転移巣の組織学 的闺連性に関与る研究. 日外会誌 $82 ： 599-611$, 1981

8）宮本徳廣, 小川道雄, 神前五郎ほか：早期胃癌括よ び早期胃癌類似進行癌の組織型とその臨床病理学 的特徵. 日消外会誌 $16: 1772-1777,1983$

9）清水 宽：早期胃癌の組織型と䫒微分光測定法に よる核 DNA 量との関保. 大阪大医誌 $29: 473$ $-489,1977$ 